\title{
Transparency and Accountability in the Finance Management of the Local Government in Promoting Good Governance
}

\author{
Prof. Dr. Tatiek Sri Djatmiati, S.H., M.S , Prof. Dr. Eman, S.H., M.S, Drs. Heru \\ Irianto, MS.i, Dr. Urip Santoso,S.H.,MH \\ Airlangga University-Indonesia
}

\begin{abstract}
The problem of corruption in Indonesia has already come to its critical point so that it cannot be tolerated anymore. During the year 2012, a number of corruption cases have been disclosed and Indonesia ranks 118 in the list of corruption perception index. Some efforts to establish the standards of public service have actually been carried out and Act No. 14 of 2008 on Public Information Disclosure has already been issued, but so far the standard of public services is still at the conceptual level, while its implementation is still far from the expectations. Consequently, good governance cannot be reached. The principles of transparency and accountability are very important and must be highly considered in the context of supervision. There are some barriers in the implementation of transparency and accountability such as the readiness of the Human Resources and the financial management system of the local government. Orderly administration and the quality of the human resources should be improved continuously to encourage transparency and accountability of the local government. Also the local officers must be equipped with the knowledge of technical legal issues.
\end{abstract}

Keywords: transparency, finance, local

\section{Introduction}

The problem of corruption in Indonesia has come to the critical point that cannot be tolerated anymore. (Idris, 2012: 1536) During 2012, a number of corruption cases have been revealed, so that Indonesia ranks 118 in the list of corruption perception index. (http://www.republika.co.id) Some efforts to establish the standards of public service have actually been carried out even Act No. 14 of 2008 on public information disclosure has already been issued; but so far the standard of the public services is still at the conceptual level, while its implementation is still far from the expectations; the services provided by various government agencies as the providers are still poor in the quality. (Yogi, M. Ikhsan, 200: 16) The implementation of the regional government autonomy results in the authority to manage the larger funds, and resources by themselves. Actually it is a great opportunity for the local governments to move forward and improve the welfare of the people. Unfortunately, what has actually happened is the contradiction. The valuable opportunity is not well applied for the benefit of the society. More fund is spent wastefully. Considering the above condition, it is necessary to design a model design of a transparent and accountable finance management of the local government resulting in good governance.

The law enforcement, accountability, transparency, open information system, participation, and managerial and technical capabilities, and organizational capacity (Mabrur M. Taufik, 2012, 1443-1447) are seriously needed to encourage the transparency and accountability in the financial management of the local government. In this regard, the study was aimed to: find out the integrated basic, technical rules and interinstitutional synergy that can be used as the guidelines in implementing the transparency and accountability in the financial management of the local government; identify any constraining factors and support the implementation of transparency and accountability in the financial management of the local government to achieve the good governance; and find out the exact model design to implement the transparency and accountability in the financial management of the local government leading to the good Governance. Considering the objectives above, a qualitative approach of Socio Legal Research (Afdol, 2008, ) was implemented in this study.

The research could be reviewed from the multidisciplinary fields of criminal law, administrative law, as well as social and political sciences, so that it could be assessed more comprehensively and holistically. Transparency and accountability are two principles of law that must be implemented in running the local government (including the financial management of the local government) in the context of good governance. Under the provisions of Act No. 32 of 2004 on the Local Government, it is stated that the autonomy is extensively granted to the local government to the extent of the governance system of the country. In the legal considerations, it is stated that the form of the autonomy contains some objectives to accelerate the achievement of the welfare of the people through some improvements of service, empowerment and participation of the 
community. It is necessary to consider the relationship among the structures of the government, the local governments, the potential and diversity of the regions for the improvement of the efficiency and effectiveness in the implementation of the autonomy. The extensive autonomy of the local government has a clear goal: to increase the welfare of the people by implementing the principles of transparency and accountability leading to the achievement of good governance.

\section{Library Studies}

\section{The nature of Accountability Transparency in Public Service}

The Transparency Principle can literally be equated with the principle of openness. It guarantees the rights of every person to obtain the correct information from the government including knowing and understanding his/her rights and positions as set forth in Constitution 1945 of the Republic of Indonesia Article 28 about the Basic Rights. Transparency is built on the free flow of the information so that information can be directly received, understood and monitored by those in need. (Hadjon. et al - 2010, p.39). Thus it is clear that the principle of transparency of the government is closely related to the human rights. In the context of the administrative law, transparency requires the government be opened by giving the correct information describing the actions or policies of the government including the financial management of the central and local government. Article 2.1 of Act No. 14 of 2008 on Public Information, determines that: Every public information is open and can be accessed by any users of the public information. Rodney A. Smollar stated about the transparency purposes: "A society that wishes to adopt openness as a value of overarching significance Merely will not allow citizens a wide range of individual expressive freedom, ....., The normal rule is that government does not conduct the business of the people behind closed door".

Thus the principles of transparency should be highly considered in all aspects relating to good governance. They are also very dominant in the areas of the financial management, and have their functions to control and supervise it. Through the transparency, it is highly expected that some leakages and power abuses in the management of the finance of the local governments can be avoided although the local governments are granted extensively in the financial management authority. There are kinds of supervision in the management of the local government called the preventive and repressive supervisions. The preventive supervision is an effort to avoid power abuses in running government, including the actions in the financial management. The repressive supervision is an effort of enforcement when the deviation occurs in running the local governance.

Thus it is well understood that transparency is not only related to the prevention but also the enforcement efforts. In the aspect of administrative law, transparency has the objective to solicit the input from the community, and it is closely related to the role of the (inspraak) citizens in the policy of decision-making or government policies. Participation or inspraak can be in the forms of direct adviesering and partisipatie. Adviesering or partisipatie is directly as a part of the role or inspraak, and it should be done before making a decision about an action or taking some policies. Therefore, such objection made after the decision can not be justified because the public information disclosure has been given by the government, as determined by the Act on Public Information Disclosure.

Act No. 28 of 1999 on the Implementation of Clean Government from from the Coalition, Corruption and Nepotism determines that the principle of accountability is very important as a part of the general principle of good governmnet organizers. In connection with the principle of the accountability, the law determines that every activity of the state officials must be accountable to the people according to the provisions of the laws (Hadjon et al. p.45). Thus the principle of accountability is also a form of supervision in the context of governance. Any implementation of the government power can always be justified so that the occurance of power abuses can be easily identified, whether there has been maladministration or not. The authority of the local government in the financial management must take into account the principle of the accountability, at least the occurance of any offences in the financial management can be prevented because it is related to the audit of the public sector.

\section{Research Method}

The Socio Legal Research approach was applied in this legal study intended to examine the legal issues with the multidisciplinary approach of the administrative law and the politics and social sciences. This study was also explored normatively and the field data were used as the material to enrich the study so that it could be observed comprehensively and holistically.

\section{Results And Discussion}

Today the concept of "good governance" has always been associated with in governance. There have been many concepts and theories of good governance stated and the major point of them mostly emphasizes on the achievement of good governance objectives. The examples were found in Act No. 32 of 2004 on the Local 
Government, Act No. 37 of 2008 on the National Ombudsman, Act No. 25 of 2009 on the Public Service, and Act No. 14 of 2008 on Public Information.

The concept and the interpretation of good governance are meant as the good administration of the governanment (Hadjon, et al - 2010, p3). In the aspects of the administrative law, Good Governance deals with the implementatiton of both the government functions and the human rights. Thus offenses against the good governance violate not only the law but also the Constitution. Various laws have already accommodated the general principles of good governance as a manifestation of its character such as:

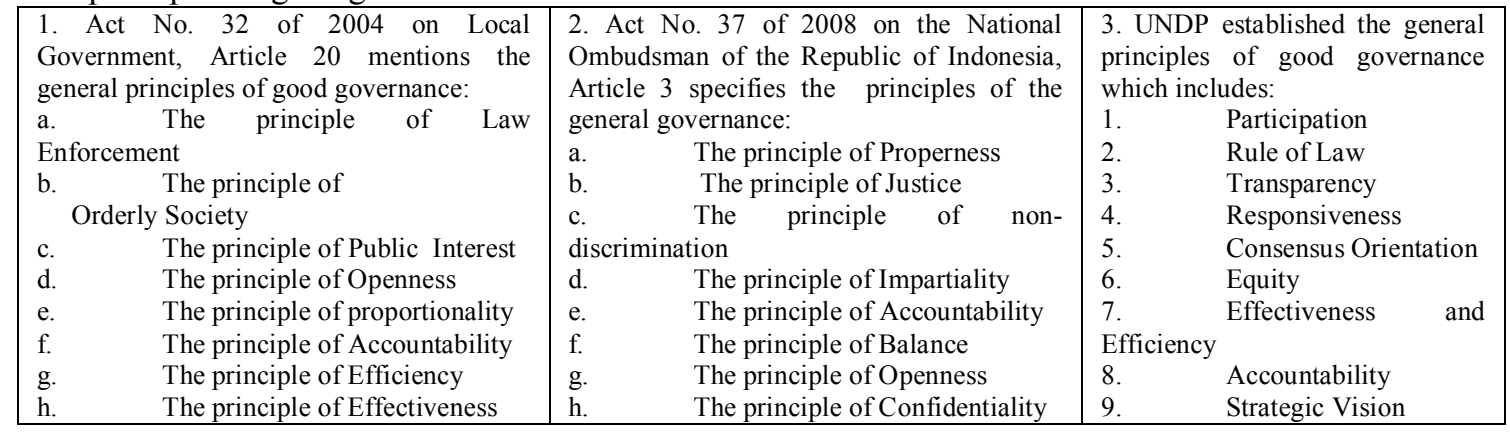

Good governance requires the implementation of those principles in running the administration of the government and the obedience to prevailing regulations, so its objectives can be achieved. It will be successful if it is supported by the constitutional law and the administrative law as the spearhead. The transparency principles have the goals. The controls and supervision towards the government must always be done by the government itself or by the public because through the transparency people can access the information, and participate in the decision making. Accountability Principle contains the objectives that should be the main parts of the responsibility of good governance. It can be carried out well, if the correct information is accepted by the society, and this is the manifestation of the principle of transparency.

In the study of administrative law, the principle of accountability is much more associated with the financial management of State and the local government, and it is very important in the implementation of good governance. White et al stated: .... Analysis of accountability relationships in public sector auditing, government conceptualized as being accountable to electorial as principal agent. (Christopher Hord \& David Heald, 2006 p.27). Referring to the above view, and the Act No. 17 of 2003 on the management of State finance in the general description, number 4 on the principle of the financial management, it is stated that the principles of universality, unity and speciality are very important in the state administration and financial management to support the achievement of good government based on the old, annual basis. There are also new thoughts about the principle which is focused on the results-oriented accountability. Thus both the principles of transparency and accountability support the achievement of good governance in running the administration of the government, including the financial management of the local government.

The real manifestations of the State's financial management, based on the order of good governance, are the financial management of the State, the responsibility, the efficiency, and the effectiveness held by the involvement of participation. (Philipus M. Hadjon., 1993:3) The Act No.14 of 2008 on Public Information Article 2 states that (1) Every Public Information is open and can be accessed by any users of Public Information. (2) Exceptional Public Information is limited and restricted. (3) Every Public Information must be able to be obtained by each applicant of the public information quickly, timely, less costly and simply. (4) Exceptional Public Information is highly confidential in accordance with the acts, decency, and common interests. The Decree of the Minister No: 63 / KEP / M.PAN / 7/2003 describes the Principles of Public Service: (1) Transparency (2) Accountability (3) Conditional (4) Participatory (5) Equal Rights (6) The balance of rights and obligations. In accordance with the principles of good governance, the financial management within the framework of the modern good financial governance must be legally set forth in the provisions of law containing the principles of transparency, and public participation. Setting the national and regional laws governing the financial management should be formulated in accordance with the meaning of good governance. The principles contained in the financial management of the State as stipulated in Act No. 17 of 2003 on State Finance, Article 3 paragraph (1) which stated: State Finance is managed orderly, efficiently, economically, effectively, transparently, and accountably, and obeys the laws and regulations with regard to the sense of justice and propriety/properness. The principles of the financial management are in line with the general principles of good governance concept. In this case the characteristics of the principles of good governance according to the United Nations Development Program (UNDP) are participation, rule of law, transparency, responsiveness, consensus orientation, equity, effectiveness and efficiency, accountability, and strategic vision. ( No Name, 2000) 
The principles of good governance presented in the Constitutional Law and Administrative Law essentially rest on two (2) foundations: the rule of law and democracy.(Philipus M. Hadjon, 2002:7) The cornerstones of the rule of law relating to the guarantees of the legal protection against the power of the government are: the implementation of the principle of legality in the administration (van wetmatigheid bestuur: a matter of authority, procedures and substances); the Rights Protection; the division of power in the government sector (such as machtsverdeling through functional and territorial decentralization); Supervision by the court (rechterlijke controle). The cornerstone of democracy is primarily concerned with the procedures and substances in good governance, both in the form of decision-making and a real deeds. The democratic principles are as follows: the legislative position, the principle of no position for the whole life, the principles of openness in the government (active and passive), and participation (Philipus M. Hadjon., 1993:5) All the affairs of the governance related to the better public policies concerning public services should also apply the principle of accountability in relation to the community/public (accountability outwards), with the subordinate officers in the government agency itself (downwards accountability), and to the senior officers (upwards accountability) (http://good-governance.bappenas)

There are some problems to meet the provisions in the financial management of the local government such as the readiness of the Human Resources (HR) in the regional governments. They cannot immediately adjust to the demands of the competences for the transparent and accountable financial management. From the political aspect, it is not easy to encourage the local officials to have the commitment in terms of the transparency in the financial management as the autonomy has not been able to take some advantages of the local finance for truly public purposes. Although the local political authorities are directly chosen by the people, in practice the people still have to strive to control them related to the use of the budget, so that it reduces the meaning of democracy. These two things make the financial management of the local government difficult to be in orderly administrative, and effectiveness and efficiency in spending the budget are hard to achieve. These all would lead to the abuse of power since control is difficult to do; Eventually Good Governance is too difficult to reach. To encourage the transparency and the accountability in the financial management, the role of the media to control the policies and the possibilities of leakage in the budget and the public interests is very important. In addition, the role of other institutions, such as the higher education or the financial regulatory bodies, to empower the local human resources is seriously needed.

\section{Conclusion}

Good governance is a form of the government that is intended to achieve the goal of the State. The principle of transparency is really important for the implementation of good governance, and the constitutional law and the administrative law are as the spearheads. The principles of transparency and accountability are very important in the context of the supervision and the legal protection of the human rights as defined in the Constitution 1945 of the Republic of Indonesia. Both principles are also intended to prevent the power abuse in governance, including the financial managements of the State and of the local government. The mismanagement and the leakage of the state and local finance can be avoided. However, there are some barriers in the implementation of transparency and accountability in financial management of the local government. They are the readiness of Human Resources, the old management system which is not easily changed to the better one which could meet the demands of the people, and the political cultures in which there are less local authorities allocate the budget for the public interest.

\section{Ssuggestion}

Orderly administration must be continously improved so that the financial accountability and effectiveness of the local government can encourage the transparency of the financial management. The local authorities must support the development of the human resources primarily related to the more technical legal issues which need more assistance from other institutions such as universities or financial supervisors; while the public control through the mass media is also very necessary to increase the motivation of the officials of the local government to do the transparency and accountability of state and local finances so that Good Governance can be achieved.

\section{Bibliography}

[1]. No Name, 2000, Lembaga Administrasi Negara dan Badan Pengawasan Keuangan Pembangunan, Akuntabilitas dan Good Governance.Jakarata

[2]. No Name, 2000.Lembaga Administrasi Negara dan Badan Pengawasan Keuangan dan Pembangunan, Akuntabilitas dan Good Governance, Lembaga Administrasi Negara dan Badan Pengawasan Keuangan dan Pembangunan, Jakarta

[3]. Afdol, 2008, Pengembangan Teori Implementasi Hukum waris Islam Di Indoensia, Pidato Pengukuhan Guru Besar, Unair, Surabaya

[4]. Hadjon Philipus M. 1993, Beberapa Catatan tentang Hukum Administrasi, Fakultas Hukum Universitas Airlangga, Surabaya,

[5]. Hadjon Philipus M. 2002, dan Sri Djatmiati Tatiek, Good Governance Dalam Penyelenggaraan Pemerintahan Daerah ( Perspektif Hukum Tata Negara dan Hukum Administrasi ) paper disampaikan dalam Seminar Nasional Good Governance Dalam 
Penyelenggaraan Pemerintahan Daerah Dalam Rangka Pemantapan Otonomi Luas, Nyata dan Bertanggung jawab, diselenggarakan oleh Universitas Warmadewa Denpasar,

[6]. Hadjon, Philipus M; dkk, 2010., Hukum Administrasi dan Good Governance, Penerbit Universitas Trisakti, Jakarta,

[7]. Hood, Christopher, \& David Heald, 2006, Transparancy, The Key to Better Governance?, Oxford University Press Inc, New York

[8]. Idris, 2012, Membongkar Akar Korupsi Di Indonesia, Jurnal Kajian Ilmiah Ubhara Jaya Volume 12 No.3 Agustus 2012, ISSN 1410-9784, Lembaga Penelitian Universitas Bhayangkara Jakarta Raya,

[9]. Jain, MP, 1997, Administrative Law of Malaysia and Singapore, Malayan Law Journal, Kuala Lumpur

[10]. Le Sueur, Andre, et. all; 1999, Principles of Public Law, Cavendish Publishing Limited, London, Second Edition,

[11]. Taufik M. Mabrur 2012, Kebijkan Pemerintah Dengan Prinsip-Prinsip Good Governance Suatu Konsep Kemampanan Sistem Manajemen Pemerintahan Jurnal Kajian Ilmiah Ubhara Jaya, Lembaga Penelitian Ubhara Jaya, Jakarta, ISSN 1410-9794, Volume 12 No.2.April, $2012: 1443-1447)$

[12]. Yogi S2 \& M. Ikhsan, 2006. Standar Pelayanan Publik Di Daerah www.pkai.lan.go.idstandar pelayanan publik

[13]. Peraturan Perundangan

[14]. U U D N RI th 1945

[15]. UU.No.32 th 2004 tentang Pemerintahan Daerah

[16]. UU. No. 14 th 2008 tentang Keterbukaa Informasi Publik

[17]. UU.No. 37 th 2008 tentang Ombudsman RI

[18]. UU. No 25 th 2009 tentang Pelayanan Publik

[19]. http://good-governance.bappenas

[20]. http://www.republika.co.id 